\section{Using a Buckwheat Cover Crop for Maximum Weed Suppression after Early Vegetables}

\author{
Thomas Björkman ${ }^{1,2,4}$ and Joseph W. Shail, Jr. ${ }^{1,3}$
}

\begin{abstract}
Additional index words.
SUMMARY. Establishment of a weed-suppressive cover crop after vegetables harvested early in the season is important in the northeastern United States because of the short growing season. Buckwheat (Fagopyrum esculentum) is an effective cover crop in vegetable production because of its short growing season, ability to outcompete many weeds, resistance to damage by insects and disease, and requirement for only moderate soil fertility. In two separate 3-year field experiments, we determined the best tillage techniques and the optimal timing for use of buckwheat as a cover crop after early vegetables in the northeastern United States. Incorporating crop residue with a disk was necessary and provided sufficient tillage to obtain a weedsuppressive buckwheat stand. Buckwheat growth was stunted when direct seeded with a no-till drill immediately after pea (Pisum sativum) harvest because of poor soil penetration by buckwheat roots. Planting buckwheat after incorporating the pea crop was successful; waiting 1 week to plant was optimal, whereas a 2 -week wait produced a weaker stand. We determined that optimal timing for sowing buckwheat in central New York was late June to early August. Generalizing to other geographical regions in the United States, we calculated that a minimum accumulation of 700 growing degree days is necessary to reach 1 to 1.5 tons/acre of buckwheat dry matter at the appropriate growth stage for incorporation ( 6 weeks after sowing).
\end{abstract}

M any vegetable growers prefer to stagger harvest over the growing season. In the northeastern United States, however, the growing season is too short to follow early-harvested cool-season crops with a second vegetable crop, but long enough that summer weeds can be problematic in fallow fields. Cover cropping can provide effective weed control, but the practice must be simple to implement. In the northeastern United States, there are few options available fitting the requirement for a rapid-growing summer cover crop. The short growing season, disease resistance, and low cost of buckwheat make it an ideal option for

This research was funded by the USDA Northeast Sustainable Agriculture Research and Education (NESARE) program

The authors are indebted to Cheryl D. Galvani for skillful editorial assistance in preparing this manuscript. Appreciation is extended to Stephen Reiners and Ryan White, Cornell University, and Carol MacNeil, Cornell Cooperative Extension, for helpful discussions and review of the manuscript; Joshua Scandrett, University of Tasmania, for assistance in field experiments; and Jessica Runnells of the Northeast Regional Climate Center, Cornell University, for the production of the buckwheat planting date map.

${ }^{1}$ Department of Horticulture, Cornell University New York State Agricultural Experiment Station, 630 W. North Street, Geneva, NY 14456

${ }^{2}$ Associate Professor of Horticulture

${ }^{3}$ Research Support Specialist

${ }^{4}$ Corresponding author. E-mail: tnbl@cornell.edu. weed control (Björkman et al., 2008; Clark, 2007; Magdoff and van Es, 2000; Sarrantonio, 1994).

Vegetable growers considering implementation of buckwheat as part of their weed management and soil conservation practices are confronted with several questions. First, is notillage (NT) planting effective and if not, how much tillage is necessary? Second, how long after incorporating buckwheat? Third, what are the earlyand late-season limits for seeding buckwheat? Fourth, what is the dry matter yield of the buckwheat cover crop? The current research addresses these questions and offers production advice on the implementation of buckwheat as a cover crop option in vegetable production.

Growers need inexpensive, simple, and effective methods for using cover crops for soil conservation and weed the crop residue must one wait to sow management. Traditionally, growers are advised to wait 2 weeks before planting a cover crop following vegetable harvest (Magdoff and van Es, 2000). Björkman (2010) recommended sowing buckwheat, to be harvested for grain, in early July in the northeastern United States. We sought to determine whether the buckwheat cover crop could be planted less than 2 weeks following pea harvest to test whether a quicker planting of the cover crop might suppress weeds even better. We also examined different planting treatments to evaluate the extent to which tillage might be reduced. Finally, we varied the date of buckwheat planting to determine when during the summer a successful stand can be established.

The incorporation of fresh organic matter can result in the presence of phytotoxins or increased microbial activity detrimental to germinating seeds and young seedlings (Cochran et al., 1977). The emergence of sweet corn (Zea mays) and lambsquarters (Chenopodium album) are negatively affected by crimson clover (Trifolium incarnatum) residue (Dyck and Liebman, 1994). Phytotoxins and microbes and/or their by-products may result in seedling mortality or loss of vigor. Therefore, planting a cover crop immediately after incorporating fresh crop residue is not recommended, and a 2-week wait is the common recommendation (Magdoff and van Es, 2000). However, that recommendation precludes many cover crops and severely reduces the possibility of double-cropping vegetables. It would, therefore, be valuable to identify alternative options to the conventional recommendations. The ultimate goal of reducing wait time is a better use of cover crops in vegetable systems, and better soil health by reducing the time that soil is bare while growing conditions are good, particularly in wet temperate climates like the Great Lakes region and much of the Atlantic

\begin{tabular}{llll}
\hline $\begin{array}{l}\text { Units } \\
\begin{array}{l}\text { To convert U.S. to SI, } \\
\text { multiply by }\end{array}\end{array}$ & U.S. unit & Sl unit & $\begin{array}{l}\text { To convert SI to U.S., } \\
\text { multiply by }\end{array}$ \\
\hline 0.4047 & $\mathrm{acre}(\mathrm{s})$ & $\mathrm{ha}$ & 2.4711 \\
0.3048 & $\mathrm{ft}$ & $\mathrm{m}$ & 3.2808 \\
0.0929 & $\mathrm{ft}^{2}$ & $\mathrm{~m}^{2}$ & 10.7639 \\
2.54 & inch $(\mathrm{es})$ & $\mathrm{cm}$ & 0.3937 \\
1.1209 & lb/acre & $\mathrm{kg} \cdot \mathrm{ha}^{-1}$ & 0.8922 \\
2.2417 & ton $/ \mathrm{acre}$ & $\mathrm{Mg} \cdot \mathrm{ha}^{-1}$ & 0.4461 \\
$\left({ }^{\circ} \mathrm{F}-32\right) \div 1.8$ & ${ }^{\circ} \mathrm{F}$ & ${ }^{\circ} \mathrm{C}$ & $\left({ }^{\circ} \mathrm{C} \times 1.8\right)+32$
\end{tabular}


Coast. Our results indicate that the 2 -week wait can be reduced under certain conditions and that 1 week may in fact be optimal.

Incorporated residue of succulent vegetables in the warm growing season can decompose more quickly than more mature plant tissue, or than during the cooler months (Parr and Papendick, 1978). Vegetable crop residue may be high in nitrogen $(\mathrm{N})$ and low in phenolics immediately following incorporation. Incorporated pea residue, in particular, contributes to high soil carbon $(\mathrm{C})$ and $\mathrm{N}$ levels as well as increased overall microbial biomass and microbial enzymatic activity (Fauci and Dick, 1994). In young pea residue, the $\mathrm{C}$ to $\mathrm{N}$ ratio $(\mathrm{C} / \mathrm{N})$ is less than 20 (Copas, 2010), which represents a $\mathrm{N}$ content that permits substantially higher decomposition rates than when $\mathrm{C} / \mathrm{N}$ is greater than 20 (Nicolardot et al., 2001). High-N residues decompose faster than low-N residues (Bruun et al., 2006; Lupwayi et al., 2004; Nicolardot et al., 2001; Sarrantonio, 2003). Legume residue with a $\mathrm{C} / \mathrm{N}$ less than 20 can provide net $\mathrm{N}$ mineralization within 10-20 d, whereas the equivalent amount of $\mathrm{N}$ in more mature residue $(\mathrm{C} / \mathrm{N}=25-50)$ can take many months to be available (Bruun et al., 2006; Sarrantonio, 2003). In fact, soil microbial activity can peak in the first week after incorporation of green pea residue (Lupwayi et al., 2004). Furthermore, buckwheat is less affected by $\mathrm{N}$ tie-up than most other cover crops, and may grow even when $\mathrm{N}$ availability is reduced by freshly incorporated residue (Stone, 1906). Nevertheless, the buckwheat seed could be sensitive to soilborne pathogens stimulated by the crop residue (Björkman, 2001).

\section{Materials and methods}

Field HISTORY. Field composition is Honeoye silt loam, and field location is the Cornell University New York State Agricultural Experiment Station Vegetable Research Farm in Geneva, NY (lat. $42^{\circ} 52^{\prime} \mathrm{N}$, long. $\left.77^{\circ} 02^{\prime} \mathrm{W}\right)$. The fields had a history of moderate compaction and relatively degraded aggregates. To simulate planting the cover crop in a vegetable rotation, we grew peas, then flail mowed at harvest maturity with a tractor-mounted mower (Standard 12 Multicrop Shredder; Loftness Manufacturing, Hector,
$\mathrm{MN}$ ) to mimic soil compaction encountered in commercial machine harvest. Peas were sown with a no-till drill (model 1560; John Deere, Moline, IL) at $100 \mathrm{lb} /$ acre on $19 \mathrm{Apr}$. 2005, 25 Apr. 2006, and 30 Apr. 2007.

Field TREATMENTS FOR TILLAge AFTER VEgETABLES. Treatment plots of $10 \times 200 \mathrm{ft}$ were assigned in a completely randomized design with four replications and the following treatments: fallow, no-tillage (NT), disk (D), chisel and disk (C), disk and wait 1 week (Dl) or 2 weeks (D2) to plant the buckwheat. Buckwheat planting dates were based on time of pea maturation and incorporation. The buckwheat planting dates for NT, C, and D were 5 July 2005 , 13 July 2006, and 18 July 2007, respectively, whereas D1 and D2 were sown 1 and 2 weeks later, respectively. Buckwheat seed [Cover Crop Seed (variety not stated); The Birkett Mills, Penn Yan, NY] was sown at $55 \mathrm{lb} /$ acre with a no-till drill.

Establishment and growth of buckwheat cover were documented by collecting stand counts at 1 and 4 weeks after seeding and biomass at 4 and 6 weeks after seeding. At 1 and 4 weeks after seeding, stand count was measured by counting the number of seedlings in a $1-\mathrm{m}^{2}$ plot placed randomly within the planting area. Buckwheat groundcover was measured using the beaded-string method (Morrison et al., 1995), with a 25 -ft string having two marks per foot strung diagonally across the width of the plot. At 4 and 6 weeks after seeding, buckwheat biomass was determined by harvesting all aboveground biomass in $1-\mathrm{m}^{2}$ plot, separating buckwheat from weeds, drying both for at least $72 \mathrm{~h}$ at $70{ }^{\circ} \mathrm{C}$ in a forced-air oven, and weighing both. The effectiveness of weed suppression by buckwheat was determined by comparing weed growth in buckwheat plots with weed growth in buckwheatfree subplots. One-square-meter subplots within each treatment were sprayed with glyphosate (Roundup WeatherMax ${ }^{\circledR}$; Monsanto, St. Louis, $\mathrm{MO}$ ) shortly after the buckwheat germinated (at 3-4 d) but before the weeds emerged (at 7-8 d). Weed dry weights in the $1-\mathrm{m}^{2}$ subplots within each treatment were determined.

Growing degree days $\left(\mathrm{GDD}_{50}\right)$ were calculated based on daily temperatures measured at a weather station at the field site on the Cornell University New York State Agricultural Experiment Station Vegetable Research Farm, Geneva, NY. The planting date map was generated by the Northeast Regional Climate Center (Cornell University, Ithaca, NY) using temperature data from 1981 to 2010 for all monitoring stations in the region. The formula identified the latest planting date in summer for which greater than $700 \mathrm{GDD}_{50}$ would accumulate in the subsequent 6 weeks. The daily normal $\mathrm{GDD}_{50}$ for 1981-2010 was summed for $42 \mathrm{~d}$ beginning after the termination of the growing season (31 Oct.), going backward in $1-d$ increments until $\mathrm{GDD}_{50}$ reached 700 , or 1 June. 31 Oct. was selected because it is known to be too late in the season for sufficient heat units to accumulate.

FIELD TREATMENTS FOR PLANTING DATE TRIAL. Fields left fallow over winter were plowed in the spring. Individual plots measured $10 \times 200 \mathrm{ft}$. The plots were planted sequentially within each of the four blocks, harrowing the ground of each strip immediately before planting buckwheat. Each strip was planted with a $10-\mathrm{ft}$ drill, at $50 \mathrm{lb} /$ acre. Plantings were done about every $10 \mathrm{~d}$, weather permitting, beginning as soon as the ground could be worked (typically mid-May) and ending just before the average first frost (25 Sept.), for a total of 7 to 10 plantings.

Statistical analyses were performed with JMP (version 9; SAS Institute, Cary, NC). The buckwheat and weed response to tillage were analyzed using a General Linear Model with treatments nested within year to estimate treatment means and to test designed contrasts. The planting date results were analyzed as a one-way analysis of variance (ANOVA) to determine the least significant difference independently for each year. The data closely fit a normal distribution, and data were analyzed accordingly.

\section{Results}

Tillage after vegetables. If buckwheat was planted directly after pea incorporation with a no-till drill, weed suppression was not satisfactory relative to the tilled treatments; but it was superior to the fallow treatment, in which weeds quickly established (Fig. 1). Buckwheat emergence was similar in all treatments, although NT 
resulted in lighter green seedlings (Fig. 1), forecasting their subsequent weak growth. Incorporating crop residue with a disk provided sufficient tillage; chisel plowing to fracture the plow layer was not necessary (Fig. 1). When buckwheat was planted 2 weeks following disking, germinated weed seedlings were already large enough to compete with the buckwheat seedlings (Fig. 1). Weed competition was less problematic when buckwheat was planted 1 week following pea incorporation and disking.

In the NT treatments, there was no loss of plants during vegetative growth (Table 1) because of selfthinning or root rot and no reduction in seedling emergence (Table 2 ). The NT buckwheat produced only half as much dry matter at harvest as the tilled treatments (Table 3 ). The tilled treatments resulted in $\approx 95 \%$ weed control, whereas, the NT treatment gave only $\approx 65 \%$ weed control (Table 4 ). The poorer NT performance was due to slower buckwheat growth and not to a reduced stand.

The conditions needed for chisel plowing to make a difference (e.g., ponding after rainfall) did not occur, therefore, this treatment had no effect in the present trial. Fracturing the pan layer by chisel plowing did not improve stand establishment (Table 1 ) nor seedling survival rate (Table 2 ), as it would have if poor water percolation caused seed rot (Björkman, 2001). Chisel plowing also had no effect improving buckwheat dry matter production (Table 3 ) as shallow compaction did not prevent adequate root development, and did not reduce weed populations (Table 4). We cannot exclude the possibility that chisel plowing would offer improved benefit if rain events were sufficient to cause standing water or in heavier soils.

PostinCorporation INTERVAL. Delaying the buckwheat planting by 1 week after incorporation of the pea crop improved stand (Table 1) and biomass (Table 3 ) compared with immediate planting after incorporation of the pea crop. Increasing the interval between pea incorporation and seeding buckwheat to the typical 2 weeks reduced buckwheat stand and growth. Weed control was not diminished by shortening the wait time.

Planting Date. For optimal weed suppression, buckwheat must quickly

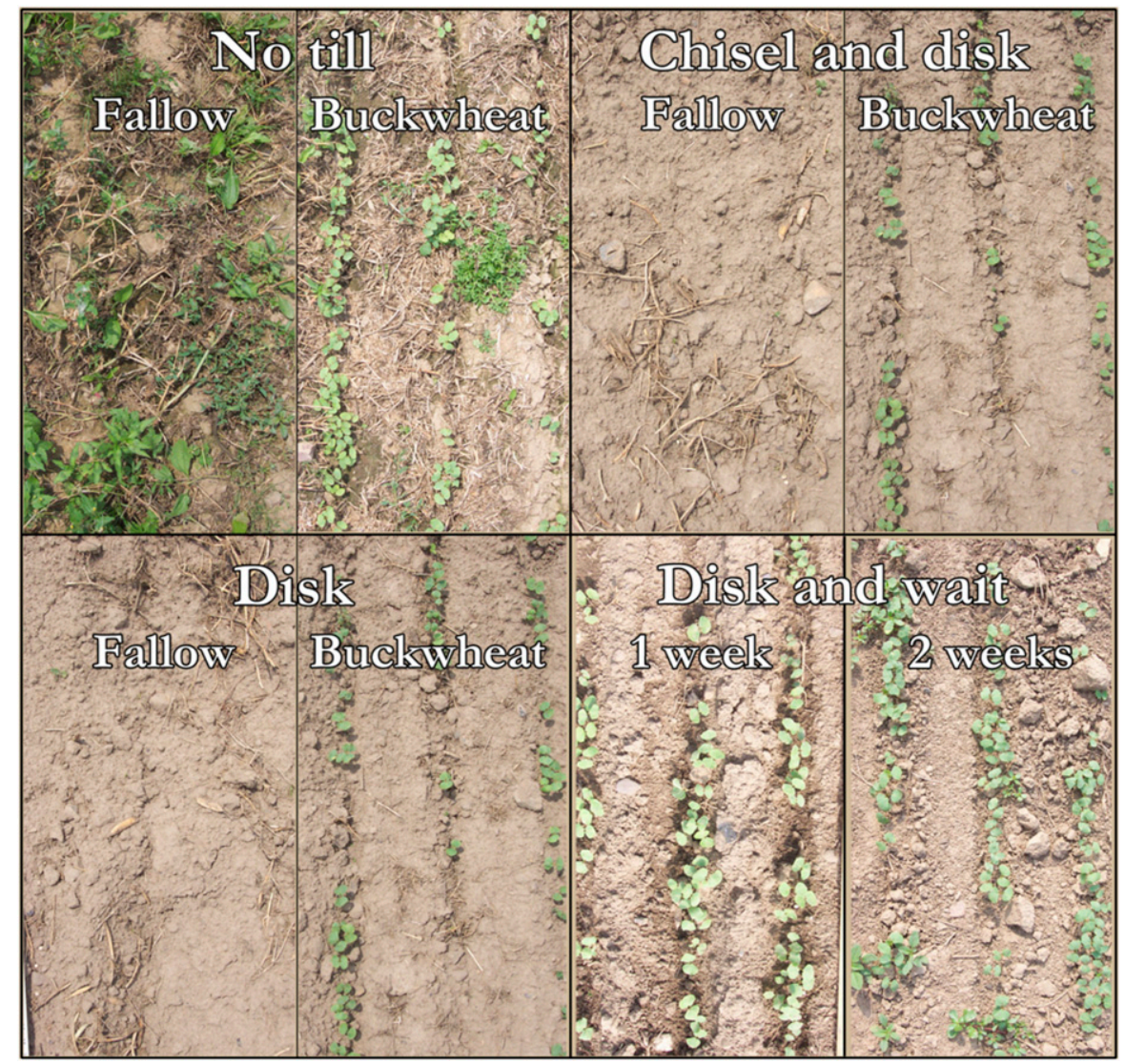

Fig. 1. Early establishment of buckwheat seedlings and weeds after pea incorporation following different treatments in 2005. Treatments are indicated on each photo. Photos were taken $7 \mathrm{~d}$ after seeding buckwheat cover crop in the respective treatments. Fallow treatments planted 1 week (D1) or 2 weeks (D2) after incorporation by disking looked similar to the fallow treatments planted immediately after disking (D) or chisel plowing and disking (C) at the same time point (data not shown). In the no-tillage treatment, established weeds continued to grow; buckwheat seedlings came up quickly but were noticeably paler than in the tilled treatments. In the treatment in which buckwheat was seeded 2 weeks after disking (D2), weed seedlings emerged before or at the same time as buckwheat.

Table 1. Optimum treatment in establishment of a buckwheat stand 1 week after sowing was determined using test of contrasts, pooled over 3 years.

\begin{tabular}{llcccc}
\hline \multicolumn{2}{c}{ Incorporation } & & $\begin{array}{c}\text { Estimated stand } \\
(\mathbf{1 0 0 0} \text { plants } / \text { acre })^{\mathbf{y}}\end{array}$ & $\boldsymbol{t}$-ratio & $\boldsymbol{P}$ \\
\hline Method & \multicolumn{1}{c}{ Contrast $^{\mathbf{z}}$} & & 9.8 & 0.607 & 0.54 \\
Tillage & NT vs. others & 15.6 & 0.765 & 0.44 \\
Plow pan & D vs. C & -61.3 & -3.45 & 0.0007 \\
Wait & D vs D1 \& D2 & $\underline{\text { D1 }}$ & 145.9 & 7.13 & $<0.0001$ \\
\hline
\end{tabular}

zNT = no-tillage, $\mathrm{D}=$ disk, $\mathrm{C}=$ chisel and disk, D1 = disk and $\mathrm{l}$-week wait, D2 = disk and 2 -week wait. Treatment in underlined bold indicates the preferred treatment at statistical significance of $P \leq 0.05$.

${ }^{\mathrm{y}}$ Mean $=486,000$ plants $/$ acre $; 1$ plant $/$ acre $=2.4711$ plants $/$ ha.

${ }^{\mathrm{x}} \mathrm{Standard}$ (i.e., recommended) wait.

provide ground coverage. We used $70 \%$ soil coverage at 3 weeks after seeding as the criterion for success because this level suppressed early weed growth in preliminary trials. In replicated trials from 2006 to $2008,60 \%$ to $70 \%$ groundcover at $20 \mathrm{~d}$ was first achieved with plantings established mid-June (Fig. 2) when $400 \mathrm{GDD}_{50}$ had accumulated since seeding (Fig. 3).

Plant vigor is dependent on warm soil and air temperatures in addition to plant genetics. Vigorous early growth, as indicated by plant height at flowering, occurs with planting dates between 
Table 2. Optimum treatment in buckwheat seedling survival at 4 weeks after sowing was determined using test of contrasts, pooled over 3 years.

\begin{tabular}{|c|c|c|c|c|}
\hline \multicolumn{2}{|c|}{ Incorporation } & \multirow{2}{*}{$\begin{array}{c}\text { Estimated stand } \\
(1000 \text { plants } / \text { acre })^{y}\end{array}$} & \multirow[b]{2}{*}{$t$-ratio } & \multirow[b]{2}{*}{$P$} \\
\hline Method & Contrast $^{\mathrm{z}}$ & & & \\
\hline Tillage & NT vs. others & 8.7 & 1.13 & 0.25 \\
\hline Plow pan & D vs. C & 14.7 & 0.71 & 0.47 \\
\hline Wait & $\mathrm{D}$ vs. D1 \& D2 & -7.3 & -0.40 & 0.68 \\
\hline Std wait ${ }^{\mathrm{x}}$ & D1 vs. D2 & 47.1 & 2.26 & 0.02 \\
\hline
\end{tabular}

${ }^{2} \mathrm{NT}=$ no-tillage, $\mathrm{D}=$ disk, $\mathrm{C}=$ chisel and disk, $\mathrm{Dl}=$ disk and $\mathrm{l}$-week wait, $\mathrm{D} 2$ = disk and 2 -week wait. Treatment in underlined bold indicates the preferred treatment at statistical significance of $P \leq 0.05$.

${ }^{\mathrm{y}} \mathrm{Mean}=450,000$ plants $/$ acre; 1 plant $/$ acre $=2.4711$ plants $/$ ha.

${ }^{x}$ Standard (i.e., recommended) wait.

Table 3. Optimum treatment in buckwheat dry matter production at 6 weeks after sowing, when buckwheat cover crop is typically ended, was determined using test of contrasts, pooled over 3 years.

\begin{tabular}{llcrcc}
\hline \multicolumn{2}{c}{ Incorporation } & & $\begin{array}{c}\text { Estimated dry matter } \\
\text { (tons/acre) }\end{array}$ & t-ratio & $\boldsymbol{P}$ \\
\hline Method & \multicolumn{1}{c}{ Contrast $^{\mathbf{z}}$} & & -0.57 & -14.67 & $<0.0001$ \\
Tillage & NT vs. others & -0.03 & -0.70 & 0.48 \\
Plow pan & D vs. C & -0.44 & -10.40 & $<0.0001$ \\
Wait & D vs. D1 \& D2 & 0.24 & 5.01 & $<0.0001$ \\
Std wait $^{\mathrm{x}}$ & D1 vs. D2 & &
\end{tabular}

${ }^{\mathrm{z}} \mathrm{NT}=$ no-tillage, $\mathrm{D}=$ disk, $\mathrm{C}=$ chisel and disk, $\mathrm{Dl}$ = disk and $\mathrm{l}$-week wait, $\mathrm{D} 2$ = disk and 2 -week wait. Treatment $(\mathrm{s})$ in underlined bold indicate the preferred treatment(s) at statistical significance of $P \leq 0.05$.

${ }^{\mathrm{y}}$ Mean $=0.84$ ton/acre; 1 ton $/$ acre $=2.2417 \mathrm{Mg} \cdot \mathrm{ha}^{-1}$.

${ }^{x}$ Standard (i.e., recommended) wait.

Table 4. Optimum treatment in weed biomass reduction in a buckwheat stand relative to that in a buckwheat-free subplot within the buckwheat plot was determined using test of contrasts, pooled over 3 years.

\begin{tabular}{llcccc}
\hline \multicolumn{2}{c}{ Incorporation } & & $\begin{array}{c}\text { Estimated weed biomass } \\
\text { reduction (\%) }\end{array}$ & t-ratio & $\boldsymbol{P}$ \\
\hline Method & \multicolumn{1}{c}{ Contrast $^{\mathbf{z}}$} & & -30 & -8.11 & $<0.0001$ \\
Tillage & NT vs. others & -4 & -0.90 & 0.36 \\
Plow pan & D vs. C & -6 & -1.63 & 0.10 \\
Wait & D vs. D1 \& D2 & 6 & 1.37 & 0.17 \\
Std wait & D1 vs. D2 & &
\end{tabular}

${ }^{2} \mathrm{NT}=$ no-tillage, $\mathrm{D}=$ disk, $\mathrm{C}=$ chisel and disk, $\mathrm{Dl}$ = disk and $\mathrm{l}$-week wait, $\mathrm{D} 2$ = disk and 2 -week wait. Treatment $(\mathrm{s})$ in underlined bold indicate the preferred treatment(s) at statistical significance of $P \leq 0.05$.

${ }^{y}$ Mean weed biomass in buckwheat stand was $74 \%$ lower than in the buckwheat-free subplot control.

${ }^{x}$ Standard (i.e., recommended) wait.

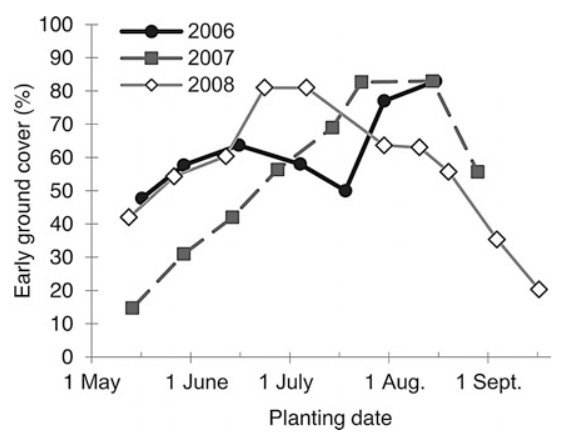

Fig. 2. Effect of planting date on early buckwheat groundcover. Groundcover was measured with the beaded-string method $20 \mathrm{~d}$ after sowing. Rapid soil cover is an important mechanism of weed suppression, and $60 \%$ to $70 \%$ early cover was sufficient to outcompete most weeds. Planting dates between 15 June and 20 Aug. resulted in sufficient groundcover to suppress weeds.

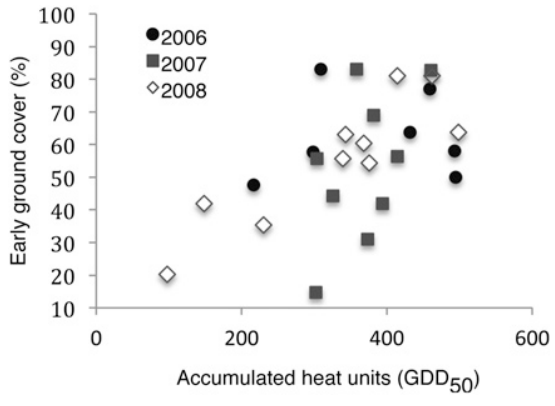

Fig. 3. Accumulated heat units, or growing degree days $\left(\mathrm{GDD}_{50}\right)$, as a predictor of buckwheat establishment. Groundcover was measured with the beaded-string method. Degree days are a useful measure if growth is temperaturelimited at similar growth stages.

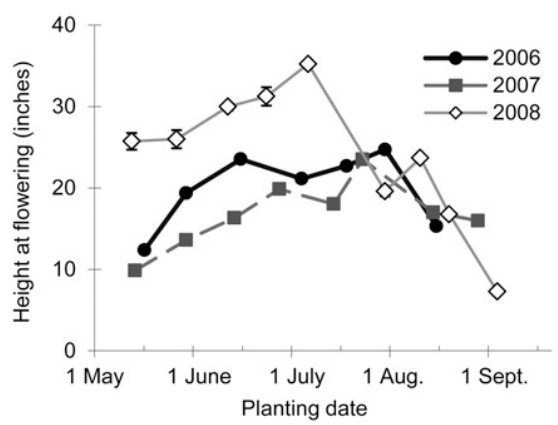

Fig. 4. Effect of planting date on buckwheat plant height at flowering. Plant height at flowering is a measure of growth close to the time when the cover crop should be ended. Flowering occurred 27 to $40 \mathrm{~d}$ after planting, depending on the temperature; 1 inch $=$ $2.54 \mathrm{~cm}$.

and 2007 (Fig. 6). In each year, biomass accumulation increased linearly with $\mathrm{GDD}_{50}$ beginning at $450 \mathrm{GDD}_{50}$ (Fig. 7), achieving maximum biomass at $700 \mathrm{GDD}_{50}$. The slope (biomass per degree day) was positively correlated to soil fertility, whereas drought or flood produced less biomass. Buckwheat requires at least $700 \mathrm{GDD}_{50}$ in 6 weeks after planting to produce sufficient biomass of 1.5 tons/acre (Fig. 7) and justify its use as a cover crop. In New York State, buckwheat must be planted by early August to achieve this minimum heat accumulation. Optimal buckwheat planting date for weed suppression was about early June to early July in all 3 years (Fig. 8). Weeds grew very little under the established buckwheat canopy, and were sometimes completely absent. The summer weeds normally present in the buckwheat-free subplots were 


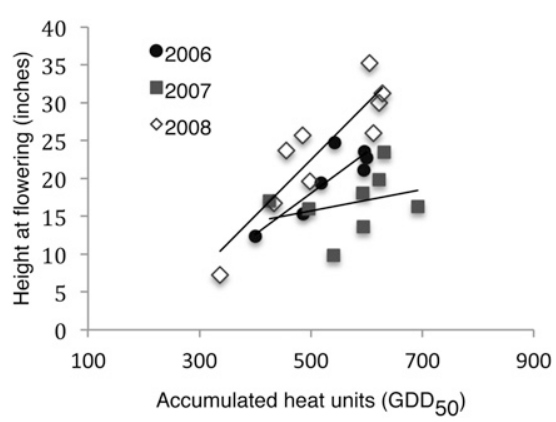

Fig. 5. Effect of accumulated heat units, or growing degree days $\left(G D_{50}\right)$, on buckwheat plant height at flowering. The lines represent the regression line for each year; 1 inch = $2.54 \mathrm{~cm}$.

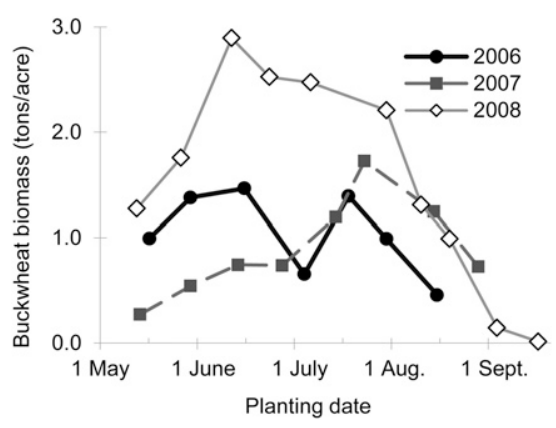

Fig. 6. Effect of planting date on buckwheat biomass at the time of incorporation ( 6 weeks after sowing). Biomass was determined by harvesting all aboveground buckwheat in $1-\mathrm{m}^{2}$ (10.8 $\left.\mathrm{ft}^{2}\right)$ plot, drying, and measuring dry weight. The least significant differences for the sequential buckwheat biomass 6 weeks after planting are: 0.23 ton/acre (2006), 0.04 ton/acre (2007), and 0.13 ton/ acre $(2008) ; 1$ ton $/$ acre $=2.2417$ $\mathrm{Mg} \cdot \mathrm{ha}^{-1}$.

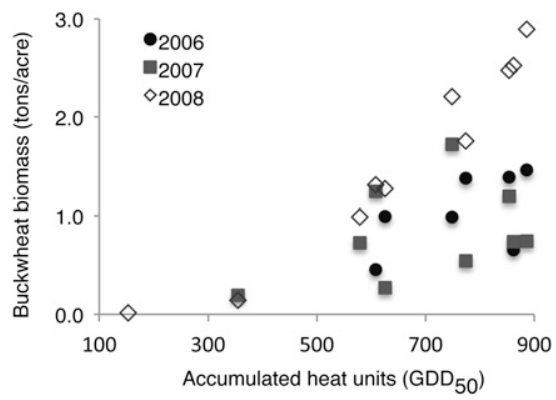

Fig. 7. Effect of accumulated heat units, or growing degree days $\left(G D_{50}\right)$, on buckwheat biomass at the time of incorporation ( 6 weeks after sowing). Biomass was determined by harvesting all aboveground buckwheat in $1-\mathrm{m}^{2}\left(10.8 \mathrm{ft}^{2}\right)$ plot, drying, and measuring dry weight; 1 ton /acre = 2.2417 Mg.ha ${ }^{-1}$. powell amaranth (Amaranthus powellii) and giant foxtail (Setaria faberi).

\section{Discussion}

Tillage is necessary for optimal weed suppression when buckwheat is used as a cover crop following earlyseason vegetables. Because of the fine root structure of buckwheat, notillage seeding into a pea crop residue is not sufficient, because the soil is too hard for buckwheat establishment. Disking provides tillage for establishment of buckwheat and subsequent weed control. Plowing is excessive tillage under normal conditions and can be omitted to preserve soil condition and reduce cost.

Traditionally, waiting 2 weeks following early vegetable incorporation before planting a cover crop is recommended (Magdoff and van Es, 2000). However, in that short time, perennial weeds become established and cannot be suppressed by a subsequent cover crop. There is a tradeoff between allowing weeds to grow and waiting for inhibitors from the crop residue to subside. With ample rain before buckwheat emerges, weeds grow sooner, and the balance shifts to favor earlier planting of a cover crop. It could be argued to cultivate weeds before sowing buckwheat, but vegetable production already includes more tillage steps than is good for soil health, so the best scenario would be to minimize tillage and therefore reduce the cost of establishing a cover crop. We tested the most conservative tillage for the buckwheat cover crop, but growers may choose additional cultivation for weed management if weather prevents timely planting or weed pressure is extreme. An additional benefit to a shorter wait time for sowing the cover crop would be to maximize the growing time for the fall crop, especially in regions such as the northeastern United States with short growing seasons (125-175 d). In the hope of realizing the numerous benefits of decreasing the 2 -week period, we sought to determine whether that wait could be shortened. Our results indicate that a $\mathrm{l}$-week wait following incorporation of early vegetables is sufficient and superior to a 2 -week wait. Delaying the buckwheat planting by $\mathrm{l}$ week after incorporation of the pea crop yielded improved buckwheat stands and biomass compared with planting immediately after

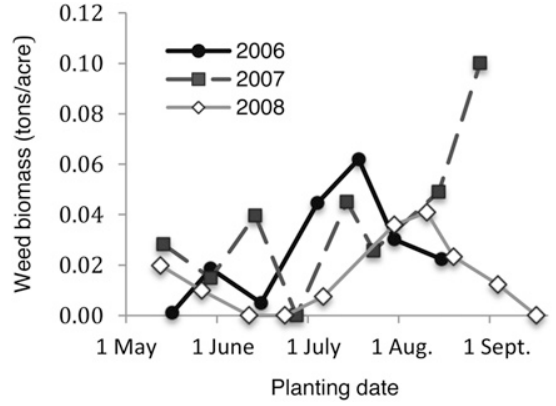

Fig. 8. Effect of buckwheat planting date on weed biomass in buckwheat stand at 6 weeks after planting. Weed biomass was determined by measuring weed dry weight at 6 weeks, the time a buckwheat cover crop would normally be ended; 1 ton $/$ acre = 2.2417 Mg.ha ${ }^{-1}$.

incorporation of the pea crop or waiting 2 weeks postincorporation. In addition, shortening the postincorporation time did not affect weed control in buckwheat.

Buckwheat suppresses weeds and produces a useful amount of biomass only if the temperature is warm enough for it to grow rapidly. Although there was considerable variation among the years examined (2006-08), a consistent pattern emerged. When the weather was cool in the spring, early buckwheat growth was too slow to outcompete weeds, but subsequent growth produced abundant biomass. In the middle of summer, when the heat accumulation was $>700 \mathrm{GDD}_{50}$, both weed suppression and growth were excellent. When planted later in the season, buckwheat seedling establishment was strong, but growth ceased before much biomass could accumulate. This pattern was used to generate a map for the northeastern United States showing the estimated last planting date for a buckwheat cover crop (Fig. 9). The dates vary over 3 months (1 June to 1 Sept.) across the region, indicating that planting-date recommendations must be location-specific.

\section{Conclusions}

Buckwheat is a successful cover crop for weed suppression after early peas. Growers should be aware that tillage is required when using buckwheat for weed control, and that disking provides sufficient tillage. Our results indicate that a $\mathrm{l}$-week wait following residue incorporation of early vegetables is sufficient, and is in fact superior to a 2 -week wait. Planting 


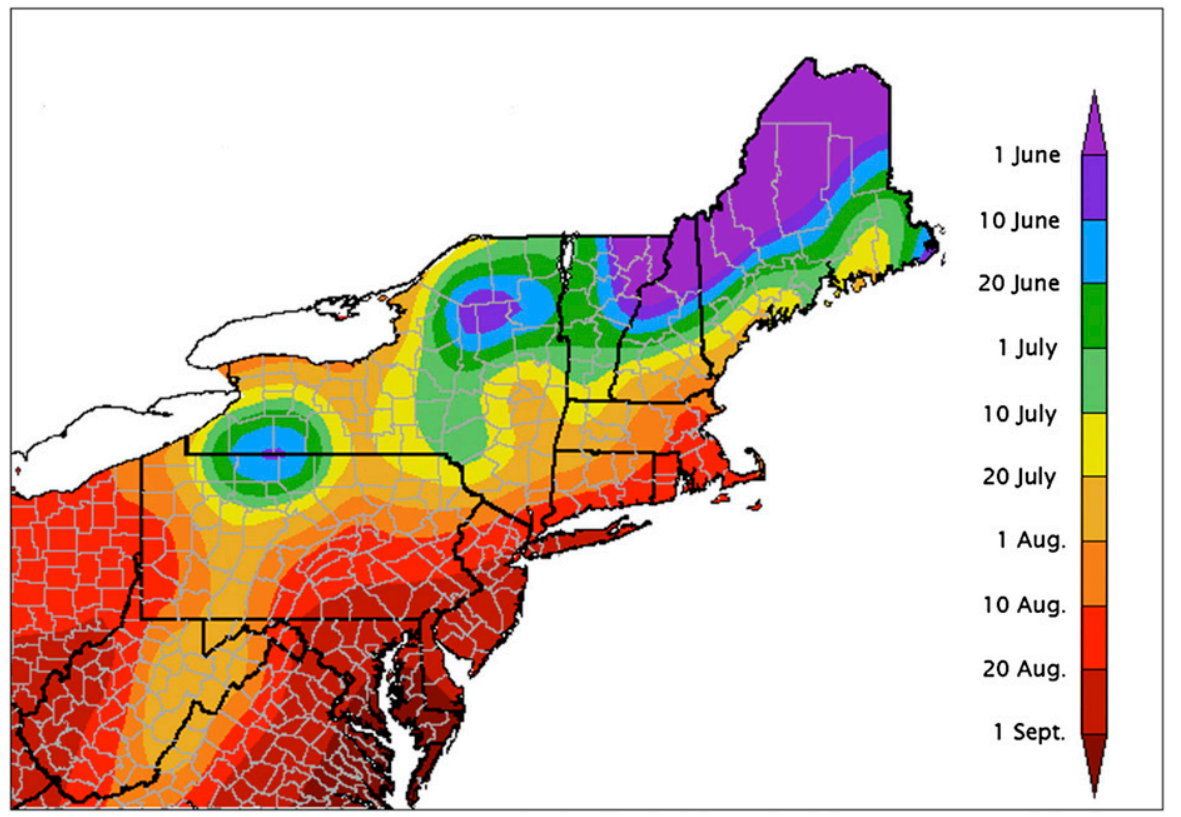

Fig. 9. Predicted last planting date for a buckwheat cover crop in the northeastern United States, assuming a minimum of 700 growing degree days in 6 weeks for a successful stand. The analysis was performed by the Northeast Regional Climate Center, Cornell University, Ithaca, NY. The map was generated from climate data collected from 1981 to 2010 . Model estimates at the extreme dates may be inaccurate if other conditions limit buckwheat growth.

buckwheat 1 week after incorporation of pea crop residue improved buckwheat stands and biomass in comparison with planting immediately or waiting 2 weeks following incorporation. The potential for rapid growth is an advantageous characteristic of buckwheat in the northeastern United States, yet temperatures must be high enough for buckwheat to thrive and produce an adequate amount of biomass to suppress weeds. A heat accumulation of $\geq 700 \mathrm{GDD}_{50}$ yielded excellent buckwheat growth and subsequent weed suppression, and therefore can be used as a guide when planting buckwheat as a cover crop. In the northeastern United States, optimal buckwheat planting dates for weed management typically range from about early June to early July.

\section{Literature cited}

Björkman, T. 2001. Causes of poor stand establishment after heavy rains, p. 134137. In: S.S. Ham, Y.S. Choi, N.S. Kim, and C.H. Park (eds.). Advances in buckwheat research. Proc. Eighth Intl. Symp. on Buckwheat. International Buckwheat Research Assn., Chunchon, Korea.

Björkman, T. 2010. Buckwheat production: Planting. 7 July 2010. Cornell Agronomy Fact Sheet Series No. 50. <http://nmsp. cals.cornell.edu/publications/factsheets/ factsheet50.pdf>.

Björkman, T., R.R. Bellinder, R.R. Hahn, and J.W. Shail. 2008. Buckwheat cover crop handbook. A precise tool for weed management on northeastern farms. New York State Agr. Expt. Sta. Bul., Cornell University, Geneva, NY.

Bruun, S., J. Luxhøi, J. Magid, A. de Neergaard, and L.S. Jensen. 2006. A nitrogen mineralization model based on relationships for gross mineralization and immobilization. Soil Biol. Biochem. 38:2712-2721.

Clark, A. (ed.). 2007. Managing cover crops profitably. 3rd ed. Sustainable Agriculture Network, Beltsville, MD.

Cochran, V.L., L.F. Elliott, and R.I. Papendick. 1977. The production of phytotoxins from surface crop residues. Soil Sci. Soc. Amer. J. 41:903-908.
Copas, M.E. 2010. Evaluation of cover cropping strategies designed for implementation into the intensively managed vegetable crop system of central Wisconsin. PhD Thesis. University of WisconsinMadison.

Dyck, E. and M. Liebman. 1994. Soil fertility management as a factor in weed control: The effect of crimson clover residue, synthetic nitrogen fertilizer, and their interaction on emergence and early growth of lambsquarters and sweet corn. Plant Soil 167:227-237.

Fauci, M. and R.P. Dick. 1994. Soil microbial dynamics: Short-and long-term effects of inorganic and organic nitrogen. Soil Sci. Soc. Amer. J. 58:801-806.

Lupwayi, N.Z., G.W. Clayton, J.T. O'Donovan, K.N. Harker, T.K. Turkington, and W.A. Rice. 2004. Soil microbiological properties during decomposition of crop residues under conventional and zero tillage. Can. J. Soil Sci. 84:411-419.

Magdoff, F. and H. van Es. 2000. Building soils for better crops. 2nd ed. Sustainable Agriculture Network Publications, Burlington, VT.

Morrison, J.E., Jr., J. Lemunyon, and H.C. Bugusch. Jr. 1995. Sources of variation of nine devices when measuring percent residue ground cover. Trans. Amer. Soc. Agr. Eng. 38:521-529.

Nicolardot, B., S. Recous, and B. Mary. 2001. Simulation of $C$ and $N$ mineralisation during crop residue decomposition: A simple dynamic model based on the $\mathrm{C}: \mathrm{N}$ ratio of the residues. Plant Soil 228:83-103.

Parr, J.F. and R.I. Papendick. 1978. Factors affecting the decomposition of crop residues by microorganisms, p. 101-129. In: Oschwald, W.R. (ed.). Crop residue management systems. ASA Spec. Publ. 31. American Society of Agronomy, Madison, WI.

Sarrantonio, M. 1994. Northeast cover crop handbook. Rodale Institute, Emmaus, PA.

Sarrantonio, M. 2003. Soil response to surface-applied residues of varying carbonnitrogen ratios. Biol. Fertil. Soils 37:175183.

Stone, J.L. 1906. Buckwheat. Cornell Univ. Agr. Expt. Sta. Bul. 238. 